\title{
Risk factors associated with Toxoplasma gondii seroprevalence in goats in the State of Paraíba, Brazil
}

\author{
Fatores de risco associados à soroprevalência de Toxoplasma gondii em caprinos do Estado da Paraíba, Brasil
}

Carolina de Sousa Américo Batista Santos ${ }^{1}$; Sérgio Santos de Azevedo²; Herbert Sousa Soares ${ }^{1}$;

Severino Silvano dos Santos Higino²; Hilda Fátima de Jesus Pena ${ }^{1}$; Clebert José Alves²; Solange Maria Gennari*

\begin{abstract}
${ }^{1}$ Animal Health and Preventive Veterinary Medicine Department, College of Veterinary Medicine and Zootechny, University of São Paulo - USP, São Paulo, SP, Brazil

${ }^{2}$ College of Veterinary Medicine, Rural Technology and Health Center, Federal University of Campina Grande - UFCG, Patos, PB, Brazil
\end{abstract}

Received September 4, 2012

Accepted September 28, 2012

\begin{abstract}
A cross-sectional study based on planned sampling was carried out to determine flock-level risk factors associated with Toxoplasma gondii antibody prevalence in dairy goat flocks in a semiarid region of northeastern Brazil. Serum samples from 975 adult dairy goats from 110 flocks were examined by indirect immonufluorescent antibody test (IFAT), using cut-off point at 1:64 dilution. From the 110 flocks, 77 presented at least one seropositive animal, corresponding to a prevalence of $70 \%$ (95\% CI: 60.5-78.4\%). Out of the 975 animals, $177(18.1 \%$; $95 \% \mathrm{CI}=15.8-20.7 \%)$ tested positive. The presence of toxic plants $(\mathrm{OR}=5.11 ; P=0.045)$ and the fact that goat breeding is not the main activity on the farm $(\mathrm{OR}=3.34 ; P=0.014)$ were identified as risk factors. The results of the present study showed evidence of the presence of $T$. gondii infection in dairy goats from a semiarid region of northeastern Brazil using planned sampling. Further studies are needed to elucidate the importance of the identified risk factors in the epidemiology of the infection.
\end{abstract}

Keywords: Toxoplasma gondii, goats, risk factors, Brazil.

\section{Resumo}

Foi conduzido um estudo transversal baseado em amostragem planejada com o objetivo de determinar fatores de risco associados com a prevalência de anticorpos contra Toxoplasma gondii, em rebanhos de caprinos leiteiros, em uma região semiárida do Nordeste do Brasil. Amostras de soro de 975 caprinos leiteiros adultos, procedentes de 110 propriedades, foram examinadas pela reaçáo de imunofluorescência indireta (RIFI), utilizando-se como ponto de corte a diluição 1:64. Das 110 propriedades, 77 apresentaram pelo menos um animal soropositivo, correspondendo a uma prevalência de 70\% (IC 95\%: 60,5-78,4\%). Dos 975 animais, 177 (18,1\%; IC 95\% = 15,8-20,7\%) foram positivos. Apesar da presença de plantas tóxicas $(\mathrm{OR}=5,11 ; P=0,045)$ e da caprinocultura não ser a principal atividade na propriedade $(\mathrm{OR}=3,34 ; P=0,014)$, foram identificados como fatores de risco. Os resultados do presente estudo mostraram uma evidência da presença da infecçáo por $T$. gondii, em caprinos leiteiros, em uma região semiárida do Nordeste do Brasil, utilizando-se uma amostragem planejada. Há necessidade de condução de estudos posteriores para elucidar a importância epidemiológica dos fatores de risco identificados.

Palavras-chave: Toxoplasma gondii, caprinos, fatores de risco, Brasil.

\footnotetext{
${ }^{*}$ Corresponding author: Solange Maria Gennari

Departamento de Medicina Veterinária Preventiva e Saúde Animal,

Faculdade de Medicina Veterinária e Zootecnia,

Universidade de Sáo Paulo - USP, Av. Prof. Dr. Orlando Marques de Paiva, 87,

Cidade Universitária, CEP 05508-270, São Paulo, SP, Brasil

e-mail: sgennari@usp.br
} 


\section{Introduction}

Toxoplasma gondii is a protozoan parasite found worldwide and it can infect a wide range of animal species, including goats; it has an indirect life cycle with felids as definitive hosts (DUBEY, 2010). In goats, T. gondii can cause abortion or neonatal mortalities (DUBEY; BEATTIE, 1988). The organism is estimated to infect $4-77 \%$ of the human population (TENTER et al., 2000). Although not normally a significant problem for healthy individuals, $T$. gondii infection can be life threatening to infants infected congenitally and pharmacologically immunosuppressed patients (CHINTANA et al., 1998). In animals, T. gondii infection not only results in significant reproduction and, hence, economic losses, but also has implications on public health, since the consumption of infected meat or milk can facilitate zoonotic transmission. T. gondii tachyzoites have been detected in milk of goats and some occurrences of human toxoplasmosis have been attributed to the consumption of non-pasteurized goat milk (SACKS et al., 1982; CHIARI; NEVES, 1984; SKINNER et al., 1990).

Goats are economically important in many countries, including Brazil, where this species is an important source of meat and milk for humans, particularly in the northeastern region, where $93.7 \%$ of the goat population is concentrated (IBGE, 2009). Dairy goat breeding is an increasing economic activity in Brazil and, in spite of the large number of animals - approximately 12 million, the country ranks only at the 18th position in terms of the amount of goat milk produced, mainly due to the low per goat milk productivity. Amongst other factors, infectious diseases such as toxoplasmosis may contribute to this problem, leading to reproduction failure (SKJERVE et al., 1998; FREYRE et al., 1999; BORDE et al., 2006).

The use of convenience sampling in epidemiological works to determine the occurrence of infectious diseases is very common and allows for the determination of important information; however, epidemiological inference should not be made based on this procedure because of the occurrence of biases. In Brazil, although many serological studies on $T$. gondii infection in goats are available, there are few works based on planned sampling. The aim of this research was to identify risk factors associated with flock-level prevalence of $T$. gondii infection in dairy goats from a semiarid region of the State of Paraíba, northeastern Brazil, based on planned sampling.

\section{Materials and Methods}

\section{Study area and sampling}

The present study was carried out from March 2009 to March 2010 in the municipality of Monteiro ( $7^{\circ} 53^{\prime} \mathrm{S}$ and $\left.37^{\circ} 5^{\prime} \mathrm{W}\right)$, Ocidental Cariri microregion, semiarid region of the State of Paraíba, northeastern Brazil. The climate is classified as semiarid and temperatures range from $18^{\circ} \mathrm{C}$ at night to $31^{\circ} \mathrm{C}$ during the day, with mean temperature of $22{ }^{\circ} \mathrm{C}$. The area is $599 \mathrm{~m}$ above sea level. Monteiro excels in the goat milk production not only in the State of Paraíba, but also in Brazil; it has the greatest number of goats in the state, in a total of 30,240 animals (IBGE, 2009).
The research was designed as a cross-sectional study of randomly selected dairy goat flocks. Blood samples were collected from female goats that were $\geq 12$ months old. A two-stage sample design was followed. First, dairy goat flocks were randomly selected. The number of flocks to be sampled was determined considering the number of dairy goat flocks in the region $(\mathrm{n}=180$, according to data of the Center for Integrated Development of Goat Production of the State of Paraíba), expected flock prevalence of 50\% (not considered a priori knowledge of the flock prevalence), and $10 \%$ desired accuracy for a 99\% level of confidence (THRUSFIELD, 2007); resulting in 86 herds to be sampled. After that, the sample size of goats to be selected was individually determined for each flock in order to detect the presence of the infection. Calculations were made in accordance with the formula commonly applied in veterinary epidemiological investigations (THRUSFIELD, 2007) (Equation 1):

$$
\mathrm{n}=\left[1-(1-\mathrm{p})^{\frac{1}{\mathrm{~d}}}\right] \times\left(\mathrm{N}-\frac{\mathrm{d}}{2}\right)+1
$$

where:

$n$ - sample size;

$p$ - probability of detection of at least one seropositive goat;

$N$ - flock size;

$d$ - number of seropositive goats in the flock.

The probability of detection of at least one seropositive goat in a flock was determined at 95\% ( $\mathrm{p}=0.95)$, and the number of seropositive goats in each flock (d) was calculated assuming prevalence of $6.4 \%$ within the flock (FIGLIUOLO et al., 2004).

Finally, from five to 12 blood samples were collected in each flock, resulting in a total number of 975 samples in 110 flocks.

For the selection of goats to be sampled from each flock, animals were put in a crush pen and then selected using systematic random sampling (THRUSFIELD, 2007). In situations where there was no handling infrastructure, true random sampling was difficult to attain. In such situations, animals were put in a kraal and randomly captured.

\section{Serum collection}

A $10 \mathrm{~mL}$ blood sample was collected from each animal from the jugular vein using vacutainer tubes. Samples were allowed to clot and transferred in ice, as quickly as possible, to the Transmissible Diseases Laboratory of the Federal University of Campina Grande, Patos, State of Paraíba, Brazil. The sera were separated by centrifugation at $2000 \mathrm{rpm}$ for 10 minutes, aspirated into Eppendorf tubes and stored at $-20{ }^{\circ} \mathrm{C}$ until testing.

\section{Epidemiological data collection}

A structured questionnaire focusing on risk factors for toxoplasmosis was conducted with each farmer at the time of blood collection. Information was collected on a total of 22 flock-level factors including: management system; main activity in the farm; flock size; predominant goat breed; presence of cattle, swine, cats, dogs and wildlife; presence of toxic plants; availability of veterinary 
services; animal purchasing; mineral supplementation; use of disposable syringes; lending of bucks for breeding; communal pasture grazing; use of disinfectants; use of maternity pens; and history of abortions, infertility, stillbirths and birth of weak animals.

\section{Serological diagnosis}

Indirect fluorescent antibody test (IFAT) was performed for detection of anti- $T$. gondii antibodies considering 1:64 dilution as cut-off point (GARCIA et al., 1999) and, according to the method by Camargo (1974), using RH strain tachyzoites as antigen. Positive and negative control goat sera were used. Anti-goat IgG (whole molecule; Sigma, St. Louis, MO, USA) was used as conjugate in a 1:400 dilution in sterile PBS $\left(0.105 \mathrm{M} \mathrm{Na}_{2} \mathrm{HPO}_{4}\right.$, 0.018 $\left.\mathrm{M} \mathrm{KH}_{2} \mathrm{PO}_{4}, 1.37 \mathrm{M} \mathrm{NaCl}, 0.027 \mathrm{M} \mathrm{KCl}\right)$, pH 7.6.

\section{Statistical analysis}

Flocks that presented at least one seropositive animal were considered positive. Prevalence of positive flocks was estimated from the ratio of positive flocks to the total number of flocks investigated, with the exact binomial confidence interval of $95 \%$ (THRUSFIELD, 2007), using EpiInfo-6.04 software program.

Risk factor analysis was performed in two steps: univariate analysis and nonlinear logistic regression model. Univariate analysis was performed using the chi-square test or Fisher's exact test (ZAR, 1999), and the variables that presented $P \leq 0.20$ were used for multiple logistic regression. Nonlinear logistic regression model was then performed using the stepwise forward method (HOSMER; LEMESHOW, 2000), with significance level of $5 \%$. Final model adjustment was verified by the Hosmer and Lemeshow test, and $P \geq 0.05$ was considered to indicate satisfactory fit. Collinearity between independent variables was assessed by correlation analysis, and when two variables were highly collinear (correlation coefficient $>0.90$ ), only one variable was likely to enter the nonlinear logistic regression model; therefore, the selection of which collinear variable to enter the model was guided by biological plausibility (DOHOO et al., 1996). The tests were performed using SPSS for Windows - version 13.0 software package.

\section{Results}

From the 110 flocks, 77 presented at least one seropositive animal for $T$. gondii, corresponding to a prevalence of $70 \%$ (95\% CI: 60.5-78.4\%). Within-flock prevalence ranged from $8.3 \%$ to $85.7 \%$. Out of the 975 animals, 177 (18.1\%; $95 \%$ CI $=15.8-20.7 \%$ ) tested positive for $T$. gondii antibodies.

In the univariate analysis for risk factors, the variables main activity in the farm; predominant goat breed; presence of cattle; presence of swine; presence of toxic plants; and history of abortions were associated $(P<0.20)$ with flock-level prevalence; and were then selected for multivariate analysis (Table 1 ). When these independent variables were subjected to nonlinear logistic regression model, presence of toxic plants $(\mathrm{OR}=5.11 ; P=0.045)$ and goat breeding not being the main activity in the farm $(\mathrm{OR}=3.34$; $P=0.014$ ) were identified as risk factors (Table 2).

Table 1. Univariate analysis for flock-level risk factors associated with Toxoplasma gondii infection in dairy goat flocks in the municipality of Monteiro, State of Paraíba, northeastern Brazil, from March 2009 to March 2010.

\begin{tabular}{|c|c|c|c|}
\hline Independent variables & No of flocks & No of positive flocks (\%) & $P$ \\
\hline \multicolumn{4}{|l|}{ MANAGEMENT SYSTEM } \\
\hline Intensive & 2 & $2(100)$ & \\
\hline Semi-intensive & 101 & $71(70.3)$ & \\
\hline Extensive & 7 & $4(57.1)$ & 0.500 \\
\hline \multicolumn{4}{|l|}{ MAIN ACTIVITY IN THE FARM } \\
\hline Goat breeding & 76 & $48(63.2)$ & \\
\hline Other & 34 & $29(85.3)$ & $0.019^{*}$ \\
\hline \multicolumn{4}{|l|}{ FLOCK SIZE } \\
\hline$\leq 25$ goats & 53 & $37(69.8)$ & \\
\hline$>25$ goats & 57 & $40(70.2)$ & 1.000 \\
\hline \multicolumn{4}{|l|}{ PREDOMINANT GOAT BREED } \\
\hline Purebred & 7 & $3(42.9)$ & \\
\hline Mixed-bred & 103 & $74(71.8)$ & $0.194^{*}$ \\
\hline \multicolumn{4}{|l|}{ PRESENCE OF CATTLE } \\
\hline No & 35 & $29(82.9)$ & \\
\hline Yes & 75 & $48(64)$ & $0.074^{*}$ \\
\hline \multicolumn{4}{|l|}{ PRESENCE OF SWINE } \\
\hline No & 79 & $60(75.9)$ & \\
\hline Yes & 31 & $17(54.8)$ & $0.052^{*}$ \\
\hline \multicolumn{4}{|l|}{ PRESENCE OF CATS } \\
\hline No & 80 & $59(73.8)$ & \\
\hline Yes & 30 & $18(60)$ & 0.243 \\
\hline
\end{tabular}

*Variables selected for the multivariate analysis $(P<0.20)$. 
Table 1. Continued...

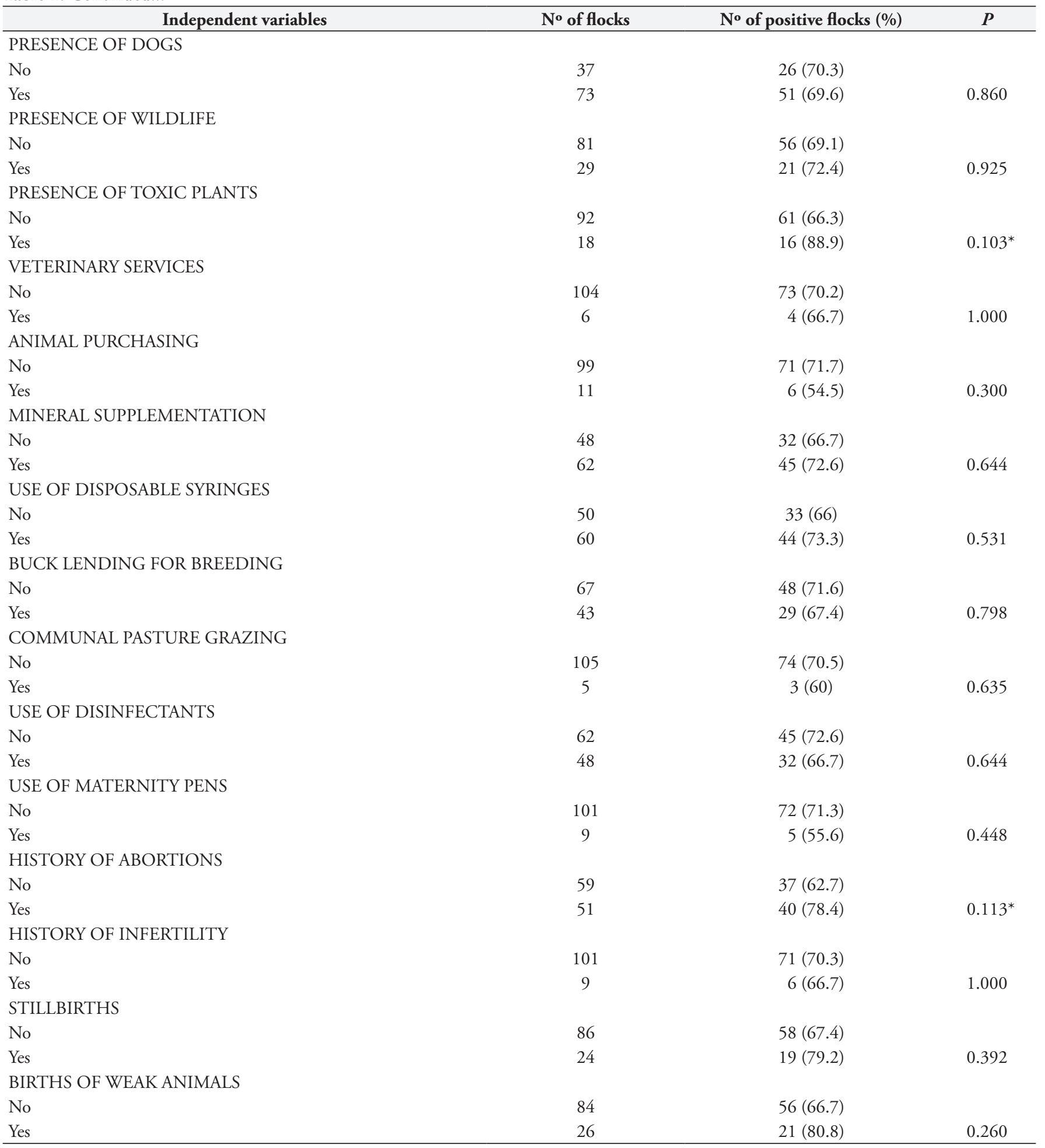

*Variables selected for the multivariate analysis $(P<0.20)$.

\section{Discussion}

Several researches on T. gondii seroprevalence in goats have been carried out in Brazil, especially in the northeast region. Frequencies of seropositive animals of $24.5 \%, 30.6 \%, 25.1 \%$ and $4.35 \%$ were reported in the states of Paraíba, Rio Grande do Norte, Ceará and Maranhão, respectively (FARIA et al., 2007; ARAÚJO NETO et al., 2008; CAVALCANTE et al., 2008; MORAES et al., 2011). All studies assessed animal-level frequency, not flock-level prevalence. In this study, the high flock-level prevalence $(70 \%)$ and within-flock prevalence $(8.3 \%$ to $85.7 \%$ ) for $T$. gondii infection in dairy goats may be associated 
Table 2. Flock-level risk factors associated with Toxoplasma gondii infection in dairy goat flocks in the municipality of Monteiro, semiarid region of the State of Paraíba, northeastern Brazil, from March 2009 to March 2010.

\begin{tabular}{lccc}
\hline \multicolumn{1}{c}{ Risk factor } & $\begin{array}{c}\text { Odds } \\
\text { ratio }\end{array}$ & $\mathbf{9 5 \%}$ CI & $\boldsymbol{P}$ \\
\hline $\begin{array}{l}\text { Presence of toxic plants } \\
\text { Goat breeding not being the main } \\
\text { activity on the farm }\end{array}$ & 3.11 & $1.03-25.30$ & 0.045 \\
\hline
\end{tabular}

Hosmer and Lemeshow test: $\chi^{2}=3.301 ; P=0.509$.

with extensive management system and unlimited contact with free-roaming cats, both of which are important risk factors (ARAÚJO NETO et al., 2008; CZOPOWICZ et al., 2011). The municipality of Monteiro is an important area for goat milk production in northeastern Brazil, and given that unpasteurized goat milk poses an important risk factor for $T$. gondii infection in humans (JONES et al., 2009), the results provided background for further public health risk analysis (CZOPOWICZ et al., 2011).

The prevalence of toxoplasmosis in different regions may range, among other factors, according to climatic conditions, presence of cats and management system (DUBEY, 2010). In Brazil, frequencies of seropositive animals have ranged from $4.35 \%$ in the State of Maranhão (MORAES et al., 2011) to 68\% in the State of Minas Gerais (BAHIA et al., 1993). The individual-level frequency of anti- $T$. gondii antibodies found in present work (18.1\%) is considered low compared to other studies, which can be explained by the fact that these animals belong to dairy flocks, where management care is more appropriate. Another factor to be considered refers to environmental and climatic conditions. The region investigated in the present work is semiarid, where climate is characterized by low humidity and rainfall volume, which may have adverse effects on the viability and environmental spread of T. gondii oocysts (DUBEY, 2010).

In the risk factor analysis for $T$. gondii, the fact that goat breeding is not the main activity in the farm was associated to flock-level prevalence. This may be explained by the use of facilities, techniques and management unsuitable for dairy goat production in these farms, as well as by the low level of organization and lack of effective sanitary control.

Another factor associated to flock-level prevalence was the presence of toxic plants. According to Robert et al. (1981), high antibody titers may be found in acute infections and in the reactivation of infections due to immunosuppression. Some toxic substances can cause immunosuppression and impair the immunity of chronically infected hosts, which become unable to control, locally, the rupture of cysts and release of tachyzoites, allowing for the reactivation of acute infections (TENTER et al., 2000). Venturini et al. (1996) reported that low and repeated doses of mycotoxins, which are enough to induce subclinical intoxication, could increase the likelihood of toxoplasma cyst rupture and, hence, the recrudescence of chronic toxoplasmosis in persistently infected mice. In the State of Paraíba, according to Riet-Correa et al. (2006), the main toxic plants for goats are Mascagnia rigida (tinguí), Prosopis juliflora (algaroba), Ipomoea asarifolia (salsa), Ipomoea carnea subsp. fistulosa ('algodão bravo'),
Leucaena leucocephala ('leucena'), Manihot spp. ('maniçobas'), Mimosa tenuiflora ('jurema preta') and Aspidosperma pyrifolium ('pereiro'). During the dry season, in areas with low fodder availability, toxic plants are often the only green plants found in pasture, and some of them present high palatability, which induces animals to eating. However, it is unclear which toxic plants from the region can cause immunosuppression and influence the prevalence of toxoplasmosis in goats. This probably happens because of the decreased capacity of intoxicated animals to control possible infections due to low infective parasitic load or less pathogenic T. gondii strains. This could be subject of further investigations.

\section{Conclusions}

The results of the present study showed evidence of the presence of $T$. gondii infection in goats from a semiarid region of northeastern Brazil using planned sampling. Further studies are needed to elucidate the importance of the identified risk factors in the epidemiology of the infection.

\section{Acknowledgements}

This study was financed by the "Conselho Nacional de Desenvolvimento Científico e Tecnológico" - CNPq, under process \#503425/2009-5. S.M. Gennari, H.F.J. Pena and S.S. Azevedo are recipients of productivity fellowships by CNPq. C.S.A.B. Santos is recipient of a scholarship by "Coordenação de Aperfeiçoamento de Pessoal de Nível Superior” - CAPES.

\section{References}

Araújo Neto JO, Azevedo SS, Gennari SM, Funada MR, Pena HFJ, Araújo ARCP, et al. Prevalence and risk factors for anti-Toxoplasma gondii antibodies in goats of the Seridó Oriental microregion, Rio Grande do Norte state, Northeast region of Brazil. Vet Parasitol 2008; 156(3-4): 329-332. PMid:18583058. http://dx.doi.org/10.1016/j.vetpar.2008.05.013

Bahia MT, Vitor RWA, Caldas R, Antunes CMF, Chiari CA. Diagnosis of caprine toxoplasmosis by a dot enzyme-linked immunosorbent assay. Arq Bras Med Vet Zootec 1993; 45(2): 173-182.

Borde G, Lowhar G, Adesiyun A. Toxoplasma gondii and Chlamydophila abortus in caprine abortions in Tobago: a sero-epidemiological study. $J$ Vet Med Series B 2006; 53(4): 188-193. PMid:16629987. http://dx.doi. org/10.1111/j.1439-0450.2006.00931.x

Camargo ME. Introdução às técnicas de imunofluorescência. Rev Bras Patol Clin 1974; 10(3): 143-171.

Cavalcante ACR, Carneiro M, Gouveia AMG, Pinheiro RR, Vitor RWA. Risk factors for infection by Toxoplasma gondii in herds of goats in Ceará, Brazil. Arq Bras Med Vet Zootec 2008; 60(1): 36-41. http:// dx.doi.org/10.1590/S0102-09352008000100006

Chiari CA, Neves DP. Toxoplasmose humana adquirida através da ingestão de leite de cabra. Mem Inst Oswaldo Cruz 1984; 79(3): 337-340. http://dx.doi.org/10.1590/S0074-02761984000300007

Chintana T, SukthanaY, Bunyakai B, Lekkla A. Toxoplasma gondii antibody in pregnant women with and without HIV infection. Southeast Asian J Trop Med Public Health 1998; 29(2): 383-386. PMid:9886133. 
Czopowicz M, Kaba J, Szaluś-Jordanow O, Nowicki M, Witkowski L, Frymus T. Seroprevalence of Toxoplasma gondii and Neospora caninum infections in goats in Poland. Vet Parasitol 2011; 178(3-4): 339-341. PMid:21324599. http://dx.doi.org/10.1016/j.vetpar.2011.01.039

Dohoo IR, Ducrot C, Fourichon C, Donald A, Hurnik D. An overview of techniques for dealing with large numbers of independent variables in epidemiologic studies. Prev Vet Med 1996; 29(3): 221-239. http:// dx.doi.org/10.1016/S0167-5877(96)01074-4

Dubey JP, Beattie CP. Toxoplasmosis of animals and man. Boca Raton: CRC Press; 1988.

Dubey JP. Toxoplasmosis of animals and humans. 2nd ed. Boca Raton: CRC Press; 2010.

Faria EB, Gennari SM, Pena HFJ, Athayde ACR, Silva MLCR, Azevedo SS Prevalence of anti-Toxoplasma gondii and anti-Neospora caninum antibodies in goats slaughtered in the public slaughterhouse of Patos city, Paraíba State, Northeast region of Brazil. Vet Parasitol 2007; 149(1-2): 126-129. PMid:17706359. http://dx.doi.org/10.1016/j.vetpar.2007.07.009

Figliuolo LPC, Rodrigues AAR, Viana RB, Aguiar DM, Kasai N, Gennari SM. Prevalence of anti-Toxoplasma gondii and anti-Neospora caninum antibodies in goat from Sáo Paulo State, Brazil. Small Rum Res 2004; 55(1-3): 29-32. http://dx.doi.org/10.1016/j. smallrumres.2003.12.013

Freyre A, Bonino J, Falcón J, Castells D, Correa D, Casaretto A. The incidence and economic significance of ovine toxoplasmosis in Uruguay. Vet Parasitol 1999; 81(1): 85-88. PMid:9950332.

Garcia JL, Navarro IT, Ogawa L, Oliveira RC. Soroepidemiologia da toxoplasmose em gatos e cáes de propriedades rurais do município de Jaguapitá, Estado do Paraná, Brasil. Ciênc Rural 1999; 29(1): 99-104. http://dx.doi.org/10.1590/S0103-84781999000100018

Hosmer DW, Lemeshow S. Applied logistic regression. New York: John Wiley \& Sons; 2000. PMid:10886529. http://dx.doi.org/10.1002/0471722146

Instituto Brasileiro de Geografia e Estatística - IBGE. Sistema IBGE de Recuperação Automática - SIDRA. 2009 [cited 2012 Sept. 04]. Available from: http://www.sidra.ibge.gov.br/bda/.

Jones JL, Dargelas V, Roberts J, Press C, Remington JS, Montoya JG. Risk factors for Toxoplasma gondii infection in the United States. Clin Infect Dis 2009; 49(6): 878-884. PMid:19663709. http://dx.doi. org/10.1086/605433
Moraes LMB, Raimundo JM, Guimarães A, Santos HA, Macedo Junior GL, Massard CL, et al. Occurrence of anti-Neospora caninum and anti-Toxoplasma gondii IgG antibodies in goats and sheep in western Maranháo, Brazil. Rev Bras Parasitol Vet 2011; 20(4):312-317. PMid:22166386. http://dx.doi.org/10.1590/ S1984-29612011000400010

Riet-Correa F, Medeiros RMT, Dantas AFM. Plantas Tóxicas da Paraíba. Patos: Universidade Federal de Campina Grande, CSTR/HV, SEBRAE/ PB; 2006.

Robert R, Chabasse D, Hocquet P. Anti-Toxoplasma IgM studied by indirect immunofluorescence and hemagglutination elimination of false positives and negatives by adsorption of $\mathrm{IgG}$ on immobilized protein $\mathrm{A}$. Biomedicine 1981; 35(2): 61-65. PMid:7020782.

Sacks JJ, Roberto RR, Brooks NF. Toxoplasmosis infection associated with raw goat's milk. J Am Med Assoc 1982; 248(14): 1728-1732. PMid:7120593. http://dx.doi.org/10.1001/jama.1982.03330140038029

Skinner LJ, Timperley AC, Wightman D, Chatterton JM, Ho-Yen DO. Simultaneous diagnosis of toxoplasmosis in goats and goatwner's family. Scand J Infect Dis 1990; 22(3): 359-361. PMid:2371548. http://dx.doi. org/10.3109/00365549009027060

Skjerve E, Waldeland H, Nesbakken T, Kapperud G. Risk factors for the presence of antibodies to Toxoplasma gondii in Norwegian slaughter lambs. Prev Vet Med 1998; 35(3): 219-227. http://dx.doi.org/10.1016/ S0167-5877(98)00057-9

Tenter AM, Heckeroth AR, Weiss LM. Toxoplasma gondii: from animals to humans. Int J Parasitol 2000; 30(12-13): 1217-1258. http://dx.doi. org/10.1016/S0020-7519(00)00124-7

Thrusfield M. Veterinary epidemiology. 3rd ed. Oxford: Blackwell Science; 2007. PMid:17287765.

Venturini MC, Quiroga MA, Risso MA, Di Lorenzo C, Omata Y, Venturini L, et al. Mycotoxin T-2 and aflatoxin B1 as immunosuppressors im mice chronically infected with Toxoplasma gondii. J Comp Pathol 1996; 115(3): 229-237. http://dx.doi.org/10.1016/ S0021-9975(96)80081-8

Zar JH. Biostatistical analysis. 4th ed. Upper Saddle River: Prentice Hall; 1999. 